JFSR 30.1 (2014) 167-184

\title{
Living It Out
}

\section{WOMEN CRUCIFIED FOR THE SINS OF THE FATHERS}

\author{
Censorship and the Crucifixion Motif \\ in the Art of Rachael Romero \\ Adele Chynoweth
}

A just/discriminating censorship is impossible.

-Susan Sontag ${ }^{1}$

I confront stigma and injustice as a multidisciplinary artist, exemplifying and encouraging healing, transformation and empowerment through creative expression.

- Rachael Romero ${ }^{2}$

As the conveyor of Rachael Romero's personal history, I experienced injustice when I arrived in Rome to present my paper "Art Has Always Saved Me': The Crucifixion Motif in the Work of Rachael Romero" at the Religion, Nature, and Art Conference at the Missionary Ethnological Museum of the Vatican Museums in October 2011. I had traveled from Canberra, in my role as curator of the exhibition Inside: Life in Children's Homes and Institutions at the National Museum of Australia. ${ }^{3}$ Inside included the personal narrative of Rachael Romero, who was confined as a teenager during the late 1960s in the Convent of the Good Shepherd, known as The Pines, in South Australia. The series of Romero's drawings, entitled Magdalene Diaries, includes the crucifix-

${ }^{1}$ Susan Sontag, quoted by Maria Popova and Brain Pickings, "Susan Sontag and the Three Steps to Refuting Any Argument," accessed February 16, 2013, http://www.brainpickings.org/index .php/2012/06/26/susan-sontag-on-censorship.

${ }^{2}$ Rachael Romero, email correspondence with author, February 3, 2009.

${ }^{3}$ Inside: Life in Children's Homes and Institutions was on display at the National Museum of Australia from November 16, 2011, to February 26, 2012, and at the Melbourne Museum from August 29, 2013, to January 27, 2014. It will then be on display at the Western Australian Maritime Museum from March 14 to June 29, 2014, and at the Queensland Museum, Brisbane, from August 9 to November 16, 2014. 
ion motif to depict the violation of basic rights of teenage girls at the hands of those in power at The Pines.

Romero's Magdalene Diaries exemplifies her sociopolitical commentary, also demonstrated by her former work as cofounder and principal artist of the San Francisco Poster Brigade (1975-83). ${ }^{4}$ Romero, now living in New York, is an interdisciplinary artist, evident in her photography and digital media as well as her earlier mass installations, billboards, and street posters. Her film In the Shadow of Eden premiered at the Yale Center for British Art in September 2003. ${ }^{5}$ Concurrent with the creation of her artworks, Romero has led art workshops for neurodiverse adults who have been homeless and inner-city children in the New York Housing Authority. She has also taught at Pratt Institute, New York; the Bosphorus University, in Istanbul; and the Advanced Learning Lab at New York University. In 2013 Romero's work was shown in an exhibition entitled I Want the Wide American Earth: An Asian Pacific American Story at the Smithsonian Institution in Washington, D.C. The drawings that comprise Magdalene Diaries are part of the preparation for her pending film Magdalene Inferno.

Twenty-four hours before I was scheduled to present my paper, I was met by two flustered conference organizers who were fearful about the content of my presentation. This was despite the fact that my following abstract had been accepted months previously:

"Art Has Always Saved Me":

The Crucifixion Motif in the Work of Rachael Romero

Rachael Romero is a multidisciplinary artist living in New York, USA, and one of 500,000 Forgotten Australians, who, as children, experienced institutional "care." Romero's art features crucifixion motifs to convey her experiences of incarceration and slave labor in the Good Shepherd Sisters' laundry in Adelaide, South Australia. In this paper, through Romero's art, I will discuss conflicting notions of the nature of adolescent women: the state's need to curb a perceived threat of female

${ }^{4}$ Her work from this period has been recently exhibited in Spotlight on Africa and the Diaspora: Africa Collections Revealed (Victoria and Albert Museum, London, 2011); Africa and the Americas: The Legacy of the Diaspora (University of California, Santa Barbara, 2012); and Under the Big Black Sun: California Art, 1974-81(Museum of Contemporary Art, Los Angeles, 2011-12).

${ }^{5}$ At the Yale Center, the film won a Short Film Prize from Film Fest New Haven. Since then, it has screened at the Cleveland International Film Festival; Santa Fe Film Festival; Moondance (where it won the Spirit Award for short documentary), Boulder, Colorado; and Full Frame Documentary Film Festival in Durham, North Carolina, where, with the help of the New York Times and a board that included Martin Scorsese, Jonathan Demme, Ken Burns, and Barbara Kopple, it was among six shorts chosen from among more than one hundred groundbreaking documentaries to appear on a currently available DVD (see Rachael Romero "In the Shadow of Eden," February 10, 2011, http://nma.gov.au/blogs/inside/2011/02/10/in-the-shadow-of-eden/). 
juvenile delinquency versus Romero's needs at the time for nurturing and self-expression. ${ }^{6}$

Obviously, there had not been adequate consultation between conference organizers before my paper was accepted, and further discussion about my presentation during the week of the conference had prompted some alarm. I was told that my presentation could not include any criticism of the Pope or the Vatican. I knew that my paper did not include such criticism, and, to reassure them, I confidently handed over a complete copy of my paper and the accompanying PowerPoint images. As the priest flicked through the hard copy of my presentation, he raised other concerns. Further discussion revealed that mention of the Pope or the Vatican was not his only worry. The conference, coincidentally, coincided with the Ad Limina visit of the Australian Catholic bishops. The Ad Limina Apostolorum (meaning "to the threshold of the apostles") refers to the quinquennial pilgrimage to Rome that bishops are expected to fulfill in order to visit the tombs of Saints Peter and Paul and to report to the Pope on the state of their dioceses. Given the media coverage of the Australian Catholic bishops' visit, he said that my paper, which concerned the violation of children's rights in an Australian Catholic institution, might attract negative attention. The Vatican obviously thought that the Australian bishops' public relations were more important than the Religion, Nature, and Art conference, the work of the National Museum of Australia, Romero's artwork, and a discussion of the abuse of children in Catholic institutions. The priest also reacted with aversion to Romero's drawing, antiseptic bath.magdalene initiation (fig. 1) given that the nude female in the image is the subject of the nun's gaze. I explained that this artwork rep-

${ }^{6}$ The federal Senate Inquiry into the Forgotten Australians (2004) estimated that five hundred thousand children experienced institutional "care" in Australia in the twentieth century. Approximately fifty thousand Aboriginal and Torres Strait Islander children, and seven thousand Former Child Migrants from Britain and Malta, are included in this number. The remainder, and indeed the majority, of institutionalized children were Australian non-Indigenous children known as "Forgotten Australians" who were placed in care often as the result of family dislocation caused by events that are summarized as the "Six Ds"- divorce, desertion, death, disease, domestic violence, and drunkenness. See Senate Community Affairs References Committee, Forgotten Australians: A Report on Australians Who Experienced Institutional or Out-of-Home Care as Children (Canberra: Commonwealth of Australia, 2004).

It is not known how many of five hundred thousand children were placed in any of the eight Magdalene laundries in Australia. Forgotten Australians noted the lack of consistency among agencies with regard to keeping records. The absence, or ad hoc method, of record-keeping by those who ran nongovernment institutions for children, such as the Sisters of the Good Shepherd, demonstrates the lack of official scrutiny by government welfare departments. Although the Good Shepherd Sisters state that they keep admission and release records, the total number of admissions has not been published. Romero, aged fourteen in 1967, recalls there being around seventy-five "inmates" at The Pines, the average admission lasting approximately one year. Romero remembers that these young women comprised either Australian-born, non-Indigenous girls, Aboriginal or Torres Strait Islander, or first-generation Australian-born girls from migrant families (Romero, email correspondence with author, February 23, 2013). 


\section{former self condemned to death.}

\section{antiseptio bath.inagdalen inifiation}

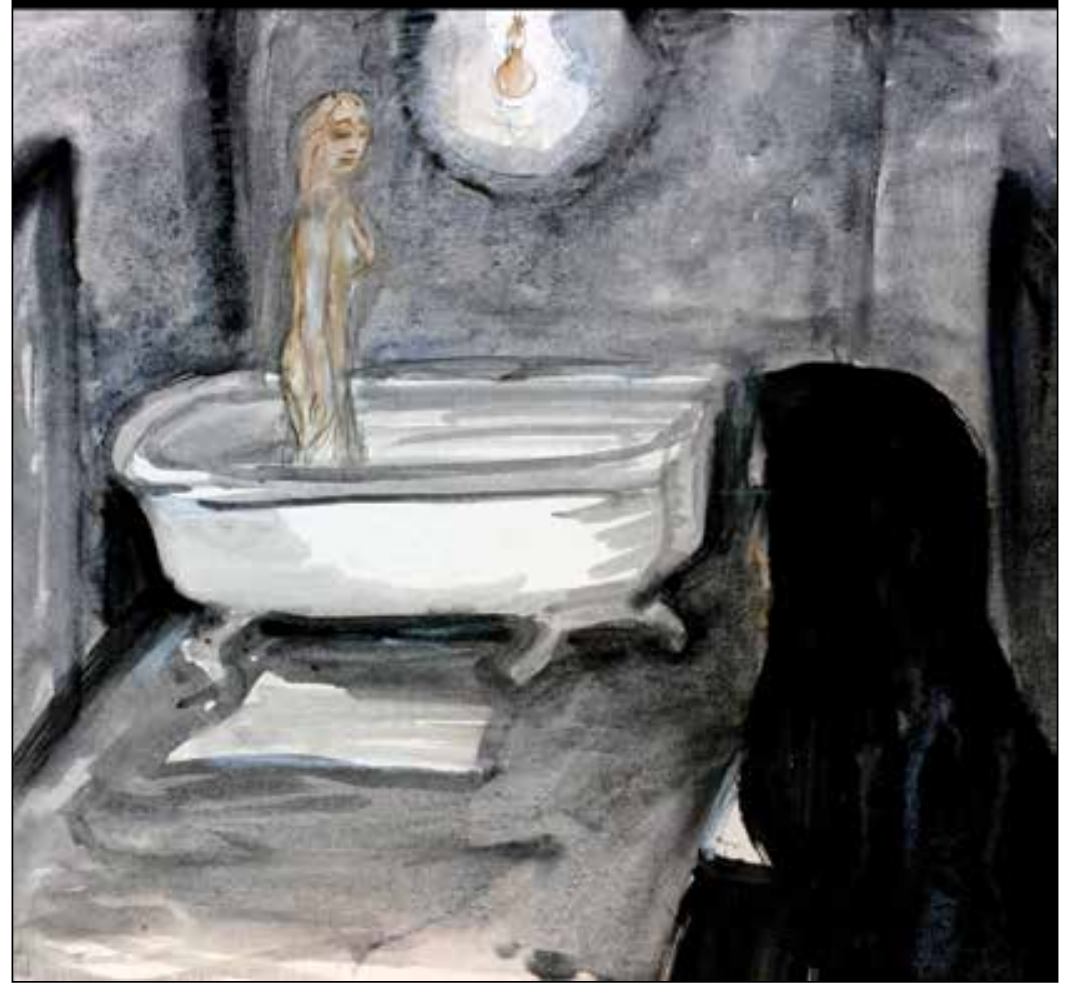

Figure 1. antiseptic bath.magdalene initiation, 2011, copyright Rachael Romero

resents an event that took place in lived reality at The Pines, and therefore the source of offense lay in the lived referent and not in the representation.

The priest was also confronted by the images of female crucifixion in my presentation. Romero uses the image of the crucified female, for example Magdalene Laundry (fig. 2), to depict the suffering she endured as a result of her incarceration and being forced to labor in a commercial laundry run by the Order of the Good Shepherd. 


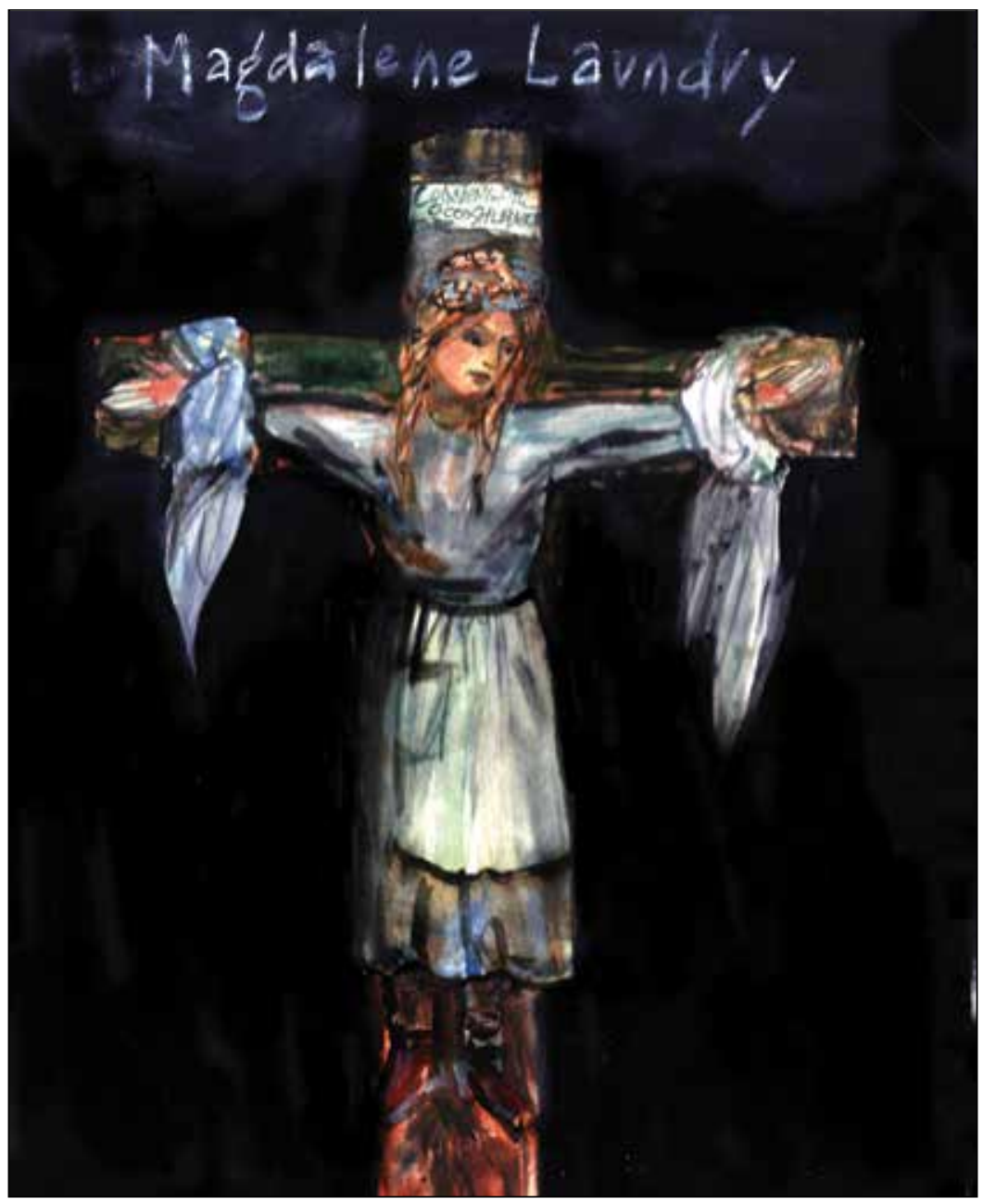

Figure 2. Magdalene Laundry, 2011, copyright Rachael Romero

Given the priest's inventory of the "dirty laundry" in my paper, he decided that he needed counsel from a higher power within the Vatican. He and another conference organizer took my paper and associated images to a manager of the Vatican Museums, who then deferred to Antonio Paolucci, director of the Vatican Museums. ${ }^{7}$ When the priest and the other conference organizers returned

${ }^{7}$ Paolucci, a historian of the Renaissance and former Italian Minister of Culture (1995-96), was appointed by Pope Benedict XVI to the role of director of the Vatican Museums. See Didier Rykner, "Antonio Paolucci, The New Director of the Vatican Museums," Art Tribune, December 7, 2007, http://www.thearttribune.com/Antonio-Paolucci-the-new-Director.html. 


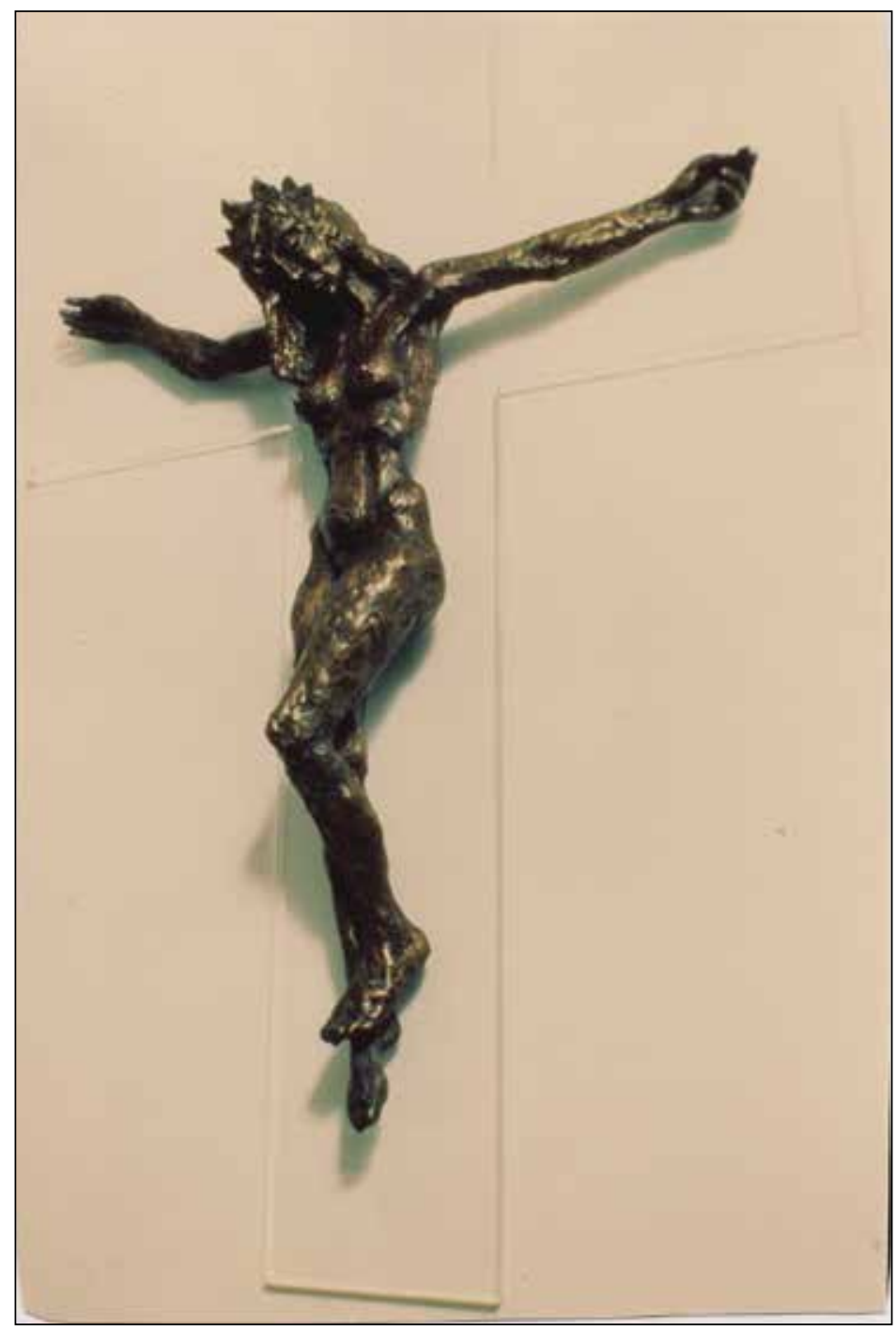

Figure 3. Christa 1974, bronze on lucite cross, 4 x 5 feet, collection of the artist. Photo: Adam Reich. Courtesy Edwina Sandys.

from Paolucci's office, they explained that I needed to cut the crucifixion images from my presentation. The priest stated that the representations of a woman on a cross were problematic in light of the Vatican's former condemnation of pop icon Madonna's staging of a mock crucifixion in Rome in 2006 as part of her 
Confessions tour. ${ }^{8}$ I was shocked that there was no understanding by Vatican staff and conference organizers of the significance of the artwork.

In order to emphasize the importance of this motif and to serve as a cultural parallel, I included in my presentation a photograph of the well-known sculpture Christa (fig. 3) by Edwina Sandys, the granddaughter of Sir Winston Churchill and a multidisciplinary artist who describes her work as characterized by social commentary. ${ }^{9}$ Three sculptures that Sandys created for the 1979 United Nations' Year of the Child are now installed in the UN Headquarters in New York. In 1997, Sandys was awarded the UN Society of Writer and Artists Award for Excellence. Her sculpture Christa, which depicts a crucified naked woman, was first displayed in London in 1975 and has been exhibited subsequently in galleries and churches throughout the United States and Canada, and in Rome. The Reverend James Parks Morton displayed Christa in the Episcopal Cathedral of Saint John the Divine, New York, in 1984 and describes the inclusive significance of Sandys's sculpture: "Christa simply reminded viewers that women as well as men are called upon to share the suffering of Christ."10

However, New York Suffragan Bishop Walter Dennis described Christa as "symbolically reprehensible" and "theologically and historically indefensible" and urged people to write letters of complaint. The ensuing protests led the sculpture to be taken down after eleven days on display. ${ }^{11}$ Late theological scholar Marcella Althaus-Reid deduced that some people deem Christa obscene because the sculpture "undresses the masculinity of God and produces feelings and questionings which were suppressed by centuries of identificatory masculine processes with God."12 Christa was brought to San Francisco by Stanford University to be displayed at the Stanford Memorial Chapel from October to December 1984. During that time, a staff member of the Center for Women and Religion within the Graduate Theological Union, Berkeley, received an image of Christa with a tail drawn on her body, entitled "Animalia."

8 "Madonna Angers Vatican," Sydney Morning Herald, August 7, 2006, http:/www.smh.com .au/news/music/madonna-accused-of-blasphemy/2006/08/07/1154802802287.html?from=rss.

9 Edwina Sandys "Recipient-1997 United Nations Society of Writers \& Artists Award for Excellence,” accessed July 5, 2012, http://www.edwinasandys.com/774041/About-the-artist.

${ }^{10}$ I first learned of Christa when I saw a copy of the sculpture hanging on the wall of Sophia, a spiritual center established in 1991 by the Dominican Sisters, in Adelaide, South Australia, to "support a feminist world view, celebrate feminist spiritualities, and seek justice for all." Sophia, "What Is Sophia?" accessed May 21, 2012, http://www.sophia.org.au/about.html.

${ }^{11}$ Julie Clague, "Symbolism and the Power of Art: Female Representations of Christ Crucified," in Bodies in Question: Gender, Religion, Text, ed. Darlene Bird and Yvonne Sherwood (London: Ashgate, 2005), 32.

${ }^{12}$ Quoted by Nicola Slee, "Visualizing, Conceptualizing, Imagining, and Praying the Christa: In Search of Her Risen Forms,” Feminist Theology 21, no. 1 (2012): 71-90, 81. 
The staff responded by displaying Christa on campus in the Badé Museum, where it was viewed by hundreds of visitors. ${ }^{13}$

Twenty-seven years after Christa was first displayed in the United States, I am surprised that images of crucified women remain objects of contention, especially when the priest from the Vatican Museums, as a liberation theologian, is renowned for his social justice work. Later, one of the conference organizers told me that it was only the "image of the naked woman on the cross" and not any of Romero's images that she described as "blasphemous" and "culturally inappropriate" that Paolucci censored. ${ }^{14}$ Whatever the rationale for this negative assessment, I understand her commentary about the "naked woman on the cross" to refer to the photo of Sandys's Christa. I reject her account because my presentation had prompted agitation prior to it being handed over to Antonio Paolucci. Additionally, art that juxtaposes nudity with the sacred could not of itself be challenging for the Vatican, an organization that ubiquitously displays the nude in its collection of Renaissance art. Clearly, then, it was not the images alone that were problematic, nor a single image at that. My presentation clearly threatened the Vatican's culture of suppression of the abuse of children in Catholic organizations and also challenged the dynamics of power of Renaissance art, which is dominated by the male gaze.

As a result of the initial concerns and the associated final, autocratic decision, I withdrew my presentation from the conference because delivering a paper that had been mutilated by the power of the Catholic Church would have betrayed the curatorial ethos of the Inside exhibition as articulated by the director of the National Museum Andrew Sayers at the exhibition opening, who explained, "This exhibition is about giving a voice to those whose voices were for so long silenced or ignored. You won't find the voices of staff or families or others concerned, only those who were children in the homes. It's their time to be heard and to be believed." ${ }^{5}$ Furthermore, not only were Forgotten Australians disbelieved, when, as children, they attempted to report the rape and torture they experienced. Later, as adults, many have struggled, often without success, to obtain records of their time in "care," to see justice fulfilled against the perpetrators of that abuse, and to obtain wages for the hours of their unpaid labor through which they survived. ${ }^{16}$ Yet again, this voice was again censored in

${ }^{13}$ Mary Cross, "Introduction: From the Publisher," Journal of Women and Religion: Special Issue Reflections on the Christa 4, no. 2 (Winter 1985): 3-5, esp. 3.

${ }^{14}$ Katherine Aigner, email correspondence with author, February 23, 2012. "[I]t was the figure of a naked woman on a cross that wasn't culturally appropriate. You were not asked to withdraw the paper, but to take out the image."

${ }^{15}$ Sayers, speaking on November 16, 2011, National Museum of Australia, Canberra.

${ }^{16}$ Senate Community Affairs References Committee, Forgotten Australians: A Report on Australians Who Experienced Institutional or Out of Home Care as Children (Canberra: Commonwealth of Australia, 2004), 13, 103, 111, 127, 128, 130, 134, 137, 210, 221, 274, and 326. 
the realm of current intellectual debate at the very forum where it needed to be heard-the Religion, Nature, and Art conference.

The insistence, by Vatican Museum staff, that I withdraw, from my presentation, the visual juxtaposition of female subjectivity with crucifixion, exemplifies Catholic hegemonic control over this symbol. It is interesting to note, however, that the Vatican is not immune from its own crucifixion controversy. Paolucci supported the Italian state's purchase, for 3.3 million Euros, of a wooden crucifix depicting a naked Christ. The sculpture is believed to be the work of Michelangelo, an assertion that some art critics dispute. ${ }^{17}$ As a result of this doubt, Italian undersecretary of state for art Roberto Cecchi and four other public servants from the Ministry of Cultural Heritage in Rome are currently on trial for not following correct protocol for the purchase of this artwork. ${ }^{18}$ What is noteworthy about this purchase is Paolucci's overt support for a depiction, created during the Renaissance, of a crucified naked male figure. His support of this aesthetic does not extend to its female-subjective, contemporary counterpart. Theologian Marcella Althaus-Reid asked in relation to representations of the crucified female: "Why, for instance, is the tortured male body of Christ less offensive and infinitely more divine than a woman's tortured body? ... Why is it that, confronted by the naked body of a female Christ, the heterosexual gaze is still fixed on the shape of breasts, the youth of the body and its sexual desirability?"19

I suspect that the decision to cut the images of crucified women may have been because the discussion in Paolucci's office took place in the absence of informed commentary of feminist Christology and associated art. ${ }^{20}$ Paolucci is an expert in Renaissance art, and the two conference conveners who showed him the images for my conference presentation had a background in postcolonial scholarship. In addition, the swift, autocratic censorship of my presentation may be indicative of the current style of governance of the Vatican overall, which has been the subject of international discussion within the Catholic Church. Such critical commentary notes that Pope John Paul II and his successor Pope Ben-

${ }^{17}$ Elisabetta Povoledo, "Yes, It's Beautiful, the Italians All Say, but Is It a Michelangelo?" New York Times, April 21, 2009.

${ }_{18}$ Art Media Agency, Italian Government Ministry Embroiled in the Case of a Fake Michelangelo, Rome, February 22, 2012, http://www.artmediaagency.com/en/tag/michelangelo/.

${ }^{19}$ Quoted by Slee, "Visualizing, Conceptualizing, Imagining, and Praying the Christa," 81.

${ }^{20}$ Christology attempts to answer Jesus's question as cited in Mark's Gospel, "Who do you think that I am?" and is thus concerned with the study of the identity and work of Jesus Christ, including the balance between his perceived humanity and divinity. Feminist Christology is a response to patriarchal religious symbolism and associated practices. Ellen K. Wondra, Humanity Has Been a Holy Thing: Toward a Contemporary Feminist Christology (Lanham, MD: University Press of America, 1994), 1-3. Feminist theologian Rosemary Ruether argues that the Christian symbols of a divine father and divine son are inadequate for women ("A Religion for Women: Sources and Strategies," Christianity and Crisis 39, no. 19 [December 1979]: 307-11). 
edict XVI, at the time of the conference in 2011, had failed to implement the reforms of Vatican II, reforms characterized by a commitment to collegiality. ${ }^{21}$

Paolucci's aversion to the image of the crucified woman can be explained in terms of theater scholar Vivian Patraka's notion of "binary terror," as defined by theater scholar Rebecca Schneider: "The terror that accompanies the dissolution of a binary habit of sense-making and self-fashioning is directly proportionate to the social safety insured in the maintenance of such apparatus of sense." 22 The image of the crucified woman interrogates the rigid boundaries between male/female and sacred/profane. The consequence for this transgression within the Vatican is censorship. Schneider notes that it is not only the contestations of meanings of representations of the female body that are significant but also who has the authority to determine those meanings: "But the issue of who has the right to author the explicit body ... in representation-or more to the point, who determines the explication of that body, what and how it means - has repeatedly been a matter of political and judicial concerns."23 Paolucci's censorship of the image of the crucified woman as constructed by female artists exemplifies the observation of the feminist theorist Marilyn Frye about male-dominated discourse: "[The] phallocentric scheme [can]not admit women as authors of perception, as seers." ${ }^{24}$

Romero's childhood was veiled by secrecy. Rachael was abused physically, sexually, and mentally by her father. By the time Rachael had turned fourteen, her father's attacks had become more violent, prompting Romero to run away from home. Her mother arranged, through the South Australian Department of Social Welfare, to have Romero incarcerated at The Pines, one of eight Magdalene laundries in Australia. Now recognized as a particularly oppressive system, the model of Magdalene laundries in Australia was imported from Ireland, where they were operated by four religious orders: Sisters of Mercy, Sisters of Charity, Sisters of the Good Shepherd, and Sisters of Our Lady of Charity of Refuge. ${ }^{25}$ However, in Australia, only the Good Shepherd Sisters established Magdalene laundries. The first four Irish Good Shepherd Sisters arrived in

${ }^{21}$ Arthur Wells, How Is Pope John's Council Faring? accessed June 10, 2012, http://vatican2 voice.org/90problems/how_faring.htm; John Wilkins "The Second Vatican Council: Fifty Years On. How Much of the Radicalism of the Event Survives Today?" The Tablet, December 31, 2011; and Peter Brock, "Reflection on Vatican II," The Swag, April 2012.

${ }_{22}$ Rebecca Schneider, The Explicit Body in Performance (New York: Routledge, 1994), 13.

${ }^{23}$ Ibid., 3.

${ }^{24}$ Ibid., 76.

${ }^{25}$ This view is articulated in Rebecca McCarthy, Origins of the Magdalene Laundries: An Analytical History (London: McFarland, 2010); and in the film The Magdalene Sisters (2002), written and directed by Peter Mullan based on the documentary Sex in a Cold Climate (1998), produced and directed by Steve Humphries. See also Carol Ryan, "Seeking Redress for a Mother's Life in a Workhouse," New York Times, February 6, 2013, http://www.nytimes .com/2013/02/07/world/europe/seeking-redress-in-ireland-over-magdalene-laundry.html?_r=0. 


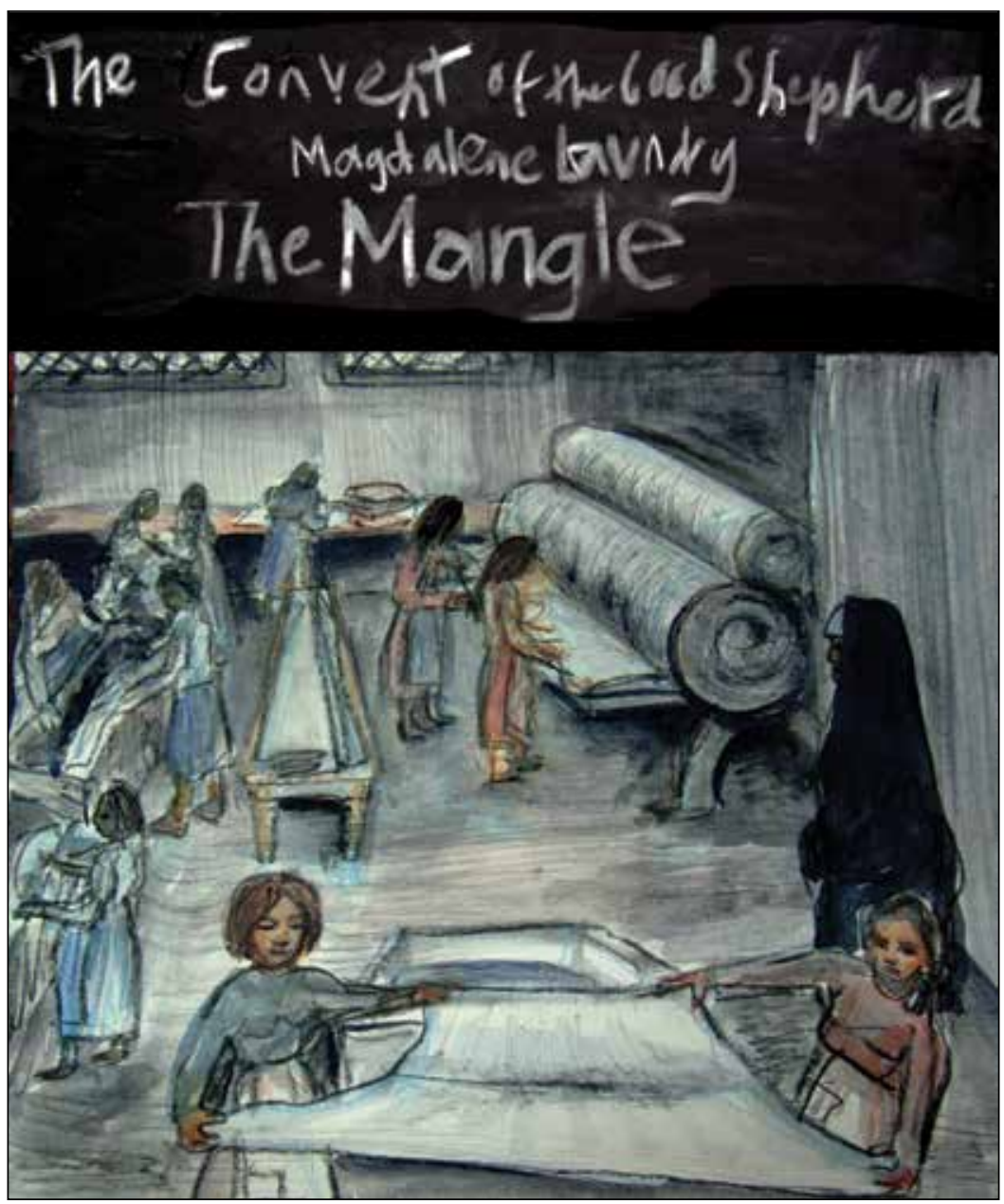

Figure 4. The Mangle, 2011, copyright Rachael Romero

Melbourne in 1863 having traveled from Angers, France, where Sister Mary Euphrasia Pelletier had founded the Congregation of Our Lady of Charity of the Good Shepherd (Good Shepherd Sisters) in 1835 to establish Magdalene houses for "fallen women." 26 These four women were led by twenty-seven-yearold Brigid Doyle, Sister Mary of St. Joseph Doyle, who established the first

${ }^{26}$ Justice for Magdalenes, fact sheet, 2, accessed December 13, 2012, http://www.magdalene laundries.com/jfm_info.pdf. 


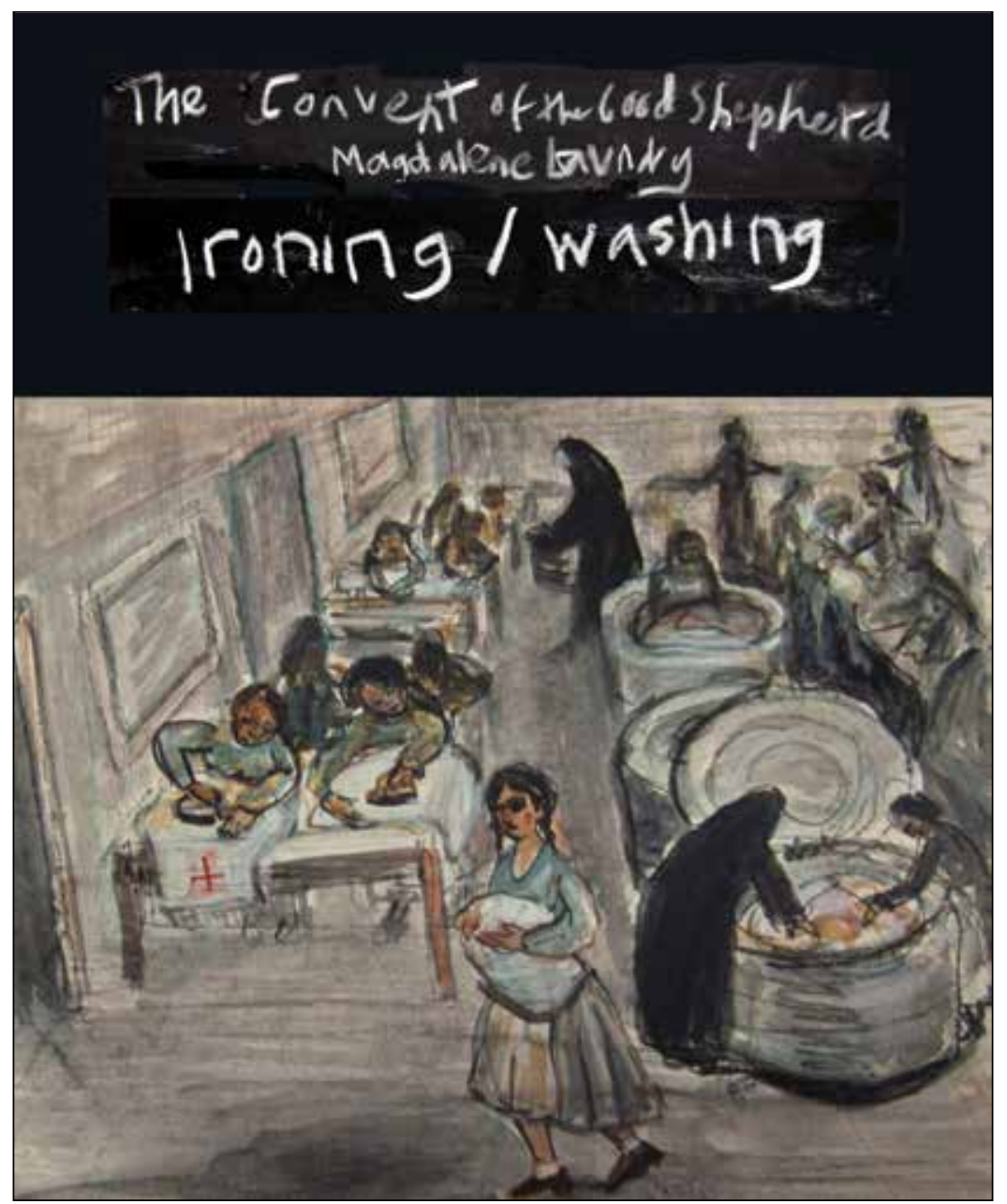

Figure 5. ironing/washing, 2011, copyright Rachael Romero

Good Shepherd Convent at Abbotsford, Victoria. ${ }^{27}$ After Sister Doyle's death in 1869, more Good Shepherd Sisters traveled to Australia from Ireland. ${ }^{28}$ In 1883, the Sisters established two other reformatory schools in the suburbs of history.

${ }^{27}$ Good Shepherd, "History," accessed February 17, 2013, http://www.goodshepherd.com.au/

${ }^{28}$ Congregation of Our Lady of Charity of the Good Shepherd, "Good Shepherd Sisters in Australia-History,” accessed February 19, 2013, http://www.buonpastoreint.org/australia_nz/ history_648. 
Melbourne, in order to reduce overcrowding at Abbotsford. Convents were also established in Tasmania, Western Australia; Bendigo (rural Victoria); New South Wales; Queensland; and South Australia.

Not only were young women incarcerated in these convents, without having committed a crime and without trial, but they were also forced to slave in the commercial laundries within these institutions. Furthermore, historian Rebecca McCarthy argues that the English colonization of Ireland resulted in different attitudes to "concepts of nation building, capital, labour, female worth and sexuality." 29 Historically, throughout the world, Magdalene targeted penitent prostitutes. ${ }^{30}$ However, in Ireland, and subsequently in Australia, prostitution became conflated with sex, including rape and incest. In this way, young women who had experienced any sexual activity, even as victims of violence, could be targeted as potentially reformed "prostitutes." This rationale for incarceration was soon extended to target any woman who did not conform with any social code, sexual or not.

Just as Romero's father's sexual abuse was kept secret, so too was the operation of the Magdalene laundry shielded from the public. Ironically, later, in 2011, the representation of the crucified female was kept secret from delegates of the Religion, Nature, and Art conference. Schneider notes that the culture of secrecy surrounds the construction of the feminine: "Secrecy is wrapped up in the cultural construction of femininity. Femininity is wrapped up in sociopolitical manipulations of secrecy." 31 This secrecy abounds in both art and lived reality as demonstrated in Romero's life and work, as well as in my attempt to publicly discuss her art. Secrecy abounds when child abuse is cast as a taboo subject.

Paolucci's censorship of the crucified female is seemingly based on the view that religious imagery cannot be simultaneously political and sacred. This response does not mark the first occasion that a representation of the female body has been censored in an intercultural event, where certain representations disrupt accepted notions of female behavior. In order to reference the 1998 Adelaide Festival's themes of spiritual performance and sacred music, an image was chosen of a Byzantine Virgin Mary seated, playing a piano accordion. ${ }^{32}$ However, leaders of the Greek Orthodox Church were angry about the poster because an image had been used with a sacred purpose but for a secular function. The church also did not approve of the depiction of the Virgin Mary without Jesus and thought that the representation of the piano accor-

29 McCarthy, Origins of the Magdalene Laundries, 136.

${ }^{30}$ This is not to argue that such historical positioning and confinement of former prostitutes was, by way of contrast, a liberating or justifiable arrangement.

${ }_{31}$ McCarthy, Origins of the Magdalene Laundries, 88.

${ }^{32}$ The poster can be viewed at http://facingsideways.wordpress.com/2011/11/24/adelaide -festival-of-arts-posters/. 


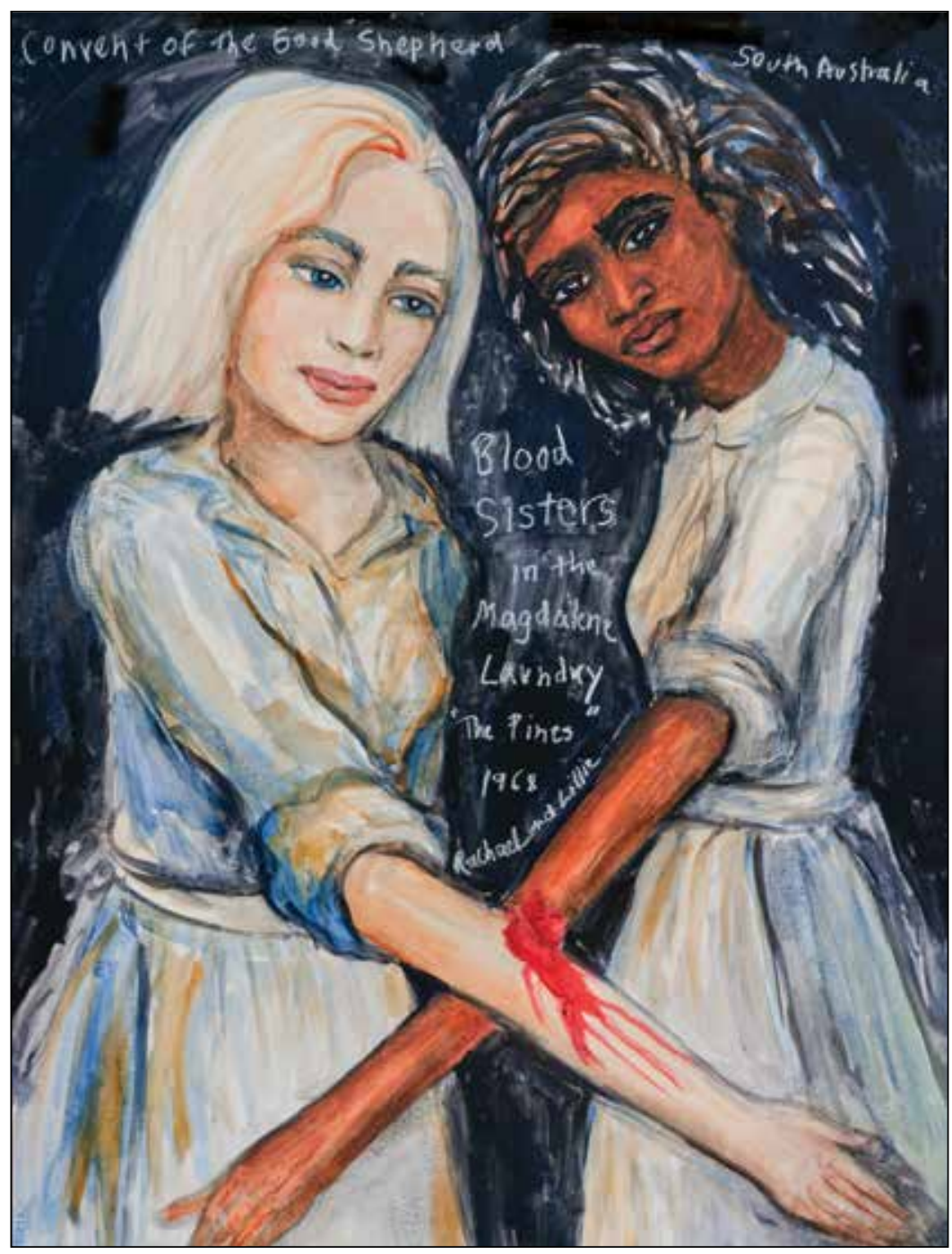

Figure 6. Blood Sisters, 2011, Rachael Romero. Ink and watercolor on rag paper.

dion mocked the church. ${ }^{33}$ In the end, a compromise was reached among men only-the Archbishop of the Greek Orthodox Church, the festival's general

${ }^{33}$ Julie Holledge and Joanne Tompkins, Women's Intercultural Performance (London: Routledge, 2000), 169. 
manager, and the chair of the Adelaide Festival Board — that the poster would not be used to promote the festival. ${ }^{34}$

The Religion, Nature, and Art conference was a similar intercultural event in which the director of the Vatican Museums censored liberating representations of the female body, thus reinforcing patriarchal control over women. Interesting to note is that, as with the censorship of the 1998 Adelaide Festival poster, the discourse of feminism was marginalized in the Vatican's response. Their focus was on the orthodox interpretation of crucifixion. Any discussion of aesthetics referred to populist culture, specifically Madonna's feigned onstage crucifixion as part of her Confessions tour. The Vatican's response confirms my central argument that female nature is not "natural" at all but socially constructed, and, in the case of Catholic orthodoxy, narrowly defined. Romero's depictions of how the Catholic Church, through incarceration and punishment, attempted to inculcate their notion of the "sinful feminine" in vulnerable teenage girls challenge the orthodox public image of a benevolent Catholic Church. The censorship of my presentation occurred in stark contrast to the postcolonial religious imagery in the Vatican Museums' collection as synchronously displayed in the Rituals of Life: Culture and Spirituality of Aboriginal Australians exhibition, which featured objects created by Aboriginal people mainly from Western Australia and the Tiwi Islands as gifts to Pope Pius XI. The Vatican deemed it culturally appropriate for Aboriginal people to combine symbols pertaining to The Dreamtime with Christian symbolism as demonstrated by the Rituals of Life exhibition. However, the director of the Vatican Museums refused the display at the conference of what could be argued as a paralleled hybridity of gender and Christianity. This parallels New York Suffragan Bishop Walter D. Dennis's 1984 assertion, in relation to the display of Christa, that he had no objections to ethnic diversity in the representation of Christ but he disapproved of female symbolism..$^{35}$ The Vatican Museums' Religion, Nature, and Art conference thus hierarchized postcolonialism over feminism. Romero's painting Blood Sisters (fig. 6) demonstrates that any hierarchization of the postcolonial gaze over the experience of non-Indigenous Australian institutionalized children is misplaced. Both Aboriginal and non-Indigenous children suffered together.

Not only had a conference paper concerning the art of Rachael Romero been censored but this censorship had also been "covered up." On my return from Italy, I learned that the third conference organizer, an academic from the United States and president of the International Society for the Study of Religion, Nature, and Culture, had not been informed about the censorship and was instead told that my absence from my presentation was due to illness. ${ }^{36}$

${ }^{34}$ Ibid., 170.

${ }^{35}$ Clague, "Symbolism and the Power of Art," 32.

${ }^{36}$ Laura Hopgood-Oster, email correspondence with author, February 23, 2012. "The information I received was that you were unwell and unable to attend." 
This narrative, constructed possibly in order to prevent further discussion and subsequent analysis of the censorship, is interesting given the fact that the observations of similar cover-ups dominated Australian media reports in 2012.

On November 12, 2012, the Prime Minister of Australia announced a Royal Commission into institutional responses to instances and allegations of child sexual abuse, proclaiming that "the allegations that have come to light recently about child sexual abuse have been heartbreaking." ${ }^{37}$ Prime Minister Julia Gillard was referring to issues that had emerged during the Parliament of Victoria's Inquiry into the Handling of Child Abuse by Religious and Other Non-Government Organisations. During the inquiry, Wayne Chamley, researcher and advocate for Broken Rites, an Australian organization that supports victims of church-related sex abuse, spoke of a group of fifteen religious brothers from the Order of Saint John of God who were involved with the sexual abuse of forty boys and the deaths of two in orphanages in the 1960s. ${ }^{38}$ Chamley also exposed a culture of "cover-up" within the Catholic Church in its dealings with allegations of child sexual abuse, specifically the order of Saint John of God in Australia. Such smoke-screen practices include moving alleged perpetrators to other countries, hiding offenders in church houses, and refusing to report alleged crimes to the police. ${ }^{39}$ Such responses do not appear to be limited to the Saint John of God brothers, but instead exemplify a repeated practice of protecting men of the cloth. ${ }^{40}$

In response to Chamley's accusations, Brother Timothy Graham, Australian head of the Brothers of Saint John of God, emphasized the actions and

${ }^{37}$ The Hon Julia Gillard MP, "Establishment of Royal Commission into Child Sexual Abuse," Media Release, November 12, 2012, Canberra, Australia, accessed December 11, 2012, http://www .pm.gov.au/press-office/establishment-royal-commission-child-sexual-abuse.

${ }^{38}$ 7.30, "Church Abuse Victims Share Stories before Royal Commission," accessed December 18, 2012, http://www.abc.net.au/7.30/content/2012/s3631167.htm.

${ }_{39}$ 7.30, "Former Nun Speaks Out on Church Abuse Claims," accessed December 16, 2012, http://www.abc.net.au/7.30/content/2012/s3651319.htm.

${ }^{40}$ Broken Rites, "Broken Rites Australia—Fighting Church Sexual Abuse since 1993," accessed December 18, 2012, http://brokenrites.alphalink.com.au/; National Museum of Australia, Inside: Life in Children's Homes and Institutions, accessed December 18, 2012, http://nma.gov .au/blogs/inside/; Justice for Magdalenes, "Welcome to Justice for Magdalenes," accessed December 18, 2012, http://www.magdalenelaundries.com/; Care Leavers of Australia Network, "Welcome to CLAN_Care Leavers Australia Network," accessed December 18, 2012, http://www .clan.org.au/; SNAP, "Survivors Network of Those Abused by Priests," accessed December 18, 2012, http://www.snapnetwork.org/; Bishop Accountability.Org, "Documenting the Abuse Crisis in the Roman Catholic Church," accessed December 18, 2012, http://www.bishop-accountability .org/; BBC News Northern Ireland, "Eighty-five Priests Were Accused of Abuse," accessed June 11, 2012, http://www.bbc.co.uk/news/uk-northern-ireland-15960621; "Roman Catholic Church Sex Abuse Cases," New York Times, accessed June 11, 2012, http://topics.nytimes.com/top/reference/ timestopics/organizations/r/roman_catholic_church_sex_abuse_cases/index.html; and "Breaking the Silence," 60 Minutes, accessed December 16, 2012, http://sixtyminutes.ninemsn.com.au/ stories/8532780/breaking-the-silence. 
motives of "individual men." ${ }^{41}$ Here, Graham espoused the beliefs of classic liberal humanism characterized by the belief in rational beings and the right to self-determination, a sense, then, that the reputation of an entire religious order should not be tarred by the actions of a few. ${ }^{42}$ However, the 1999 Commission of Inquiry into Abuse of Children in Queensland Institutions cited the causes of institutional child abuse as not only individual factors but also those pertaining to separate institutions, administrative departments, governments, and society. ${ }^{43}$ All systemic components work together, resulting in the institutionalized abuse of children.

Of course, the censorship of a conference paper does not come close, in comparison, to the perversion of justice. Nevertheless, it is interesting to note that the pending Royal Commission and Romero's Magdalene Diaries both concern institutional responses to the care of children and that the just and transparent examination of this subject has, on several occasions, been compromised by certain sectors within the Catholic Church. The censorship at the Religion, Nature, and Art conference was covertly supported by staff of the Missionary Ethnological Museum of the Vatican Museums. These same staff, through their work for the Rituals of Life exhibition, had hitherto earned their reputation of supporting spiritual and cultural diversity, a stance that would sadly fall short when presented with the image of the crucified female subject and an accompanying discussion about the rights of institutionalized children. The goodwill of individual "men" seems so easily thwarted when accompanied by systemic pressures and the need to preserve the reputations of those in power.

As a teenage girl, Rachael Romero was incarcerated for her father's crimes. She survived to draw her testimony in Magdalene Diaries. In 2011, at the Vatican Museums, the female subject, as represented on the crucifix, again was censored, denied, forbidden, and covered up. The emphasis on postcolonialism at the Religion, Nature, and Art conference resulted in the marginalization of gender. The hierachization of interculturalism over feminism is not limited to the Vatican. It has also been noted in international arts markets, exemplified by the censorship of the 1998 Adelaide Festival poster, where the views of the local Greek Orthodox community were privileged over and above feminist representation. The Vatican Religion, Nature, and Art conference not only served to reinforce this current ranking of paradigms but also closed the gates on feminist contributions to cultural hybridity. This was an act analogous to the Good Shep-

${ }^{41}$ Australian Broadcasting Commission, "Saint John of God Responds to Abuse Claims," 7.30, accessed December 16, 2012, http://www.abc.net.au/7.30/content/2012/s3649351.htm.

${ }^{42}$ I am applying the notion of liberal humanism as discussed in Chris Weedon, Feminist Practice and Poststructuralist Theory, 2d ed. (London: Blackwell, 1997), 77.

${ }^{43}$ Commission of Inquiry into Abuse of Children in Queensland Institutions, Report of the Commission of Inquiry into Abuse of Children in Queensland Institutions (Brisbane: Queensland Government, 1999), 13. 
herd Sisters' closure of the gates on those young women who did not conform to prescriptive codes of feminine "nature." This closure at the 2011 Vatican conference was masked by gestures of goodwill and apologies designed to silence public, rigorous, open, and inclusive debate of institutional abuse of the innocent. Token regret neither lifts the veil of secrecy that hides the sociopolitical manipulations of femininity nor exposes the lack of justice for hundreds of thousands, throughout the world, including the Forgotten Australians, whose rights are violated within Catholic organizations. 
information, see http://redroom.com/member/margo-berdeshevsky [margober @maui.net]

Lauren Camp is the author of two books of poems, The Dailiness (Edwin E. Smith, 2013) and This Business of Wisdom (West End Press, 2010). She was a juror for the 2014 Neustadt International Prize for Literature and guest editor for special sections in World Literature Today (on international jazz poetry) and Malpaís Review (on the poetry of Iraq). Her poems have been published in Brilliant Corners, Beloit Poetry Journal, Sweet, and Feminist Studies. A radio producer and host on Santa Fe Public Radio, Lauren is also an acclaimed visual artist (www.laurencamp.com). [lauren@laurencamp.com]

Adele Chynoweth studied theater direction at the Flinders University Drama Centre. In addition to her professional theater direction credits, in 2002 she was awarded a PhD for her research in contemporary Australian drama. In 2001, she was the researcher and writer for the Memory Museum, an official part of the South Australian celebrations of the 2001 Centenary of Federation South Australia. She was the co-curator of National Museum of Australia's exhibition Inside: Life in Children's Homes and Institutions. She is currently a Visitor within the ANU College of Arts and Social Sciences at the Australian National University, where, in 2012, she received a Vice-Chancellor's Award. [Adele .Chynoweth@anu.edu.au]

Marvin M. Ellison completed his doctoral studies in 1981 at Union Theological Seminary in New York, where he was Beverly Wildung Harrison's first doctoral advisee. He then taught Christian social ethics for thirty-two years at Bangor Theological Seminary in Maine. His latest book is Making Love Justice: Sexual Ethics for Perplexing Times (Fortress Press, 2012). He founded the Maine Interfaith Council for Reproductive Choices, a network of clergy and faith leaders who provide public education, pastoral care, and public policy advocacy in behalf of reproductive justice. [mellison122@gmail.com]

Michelle Fletcher read English as an undergraduate at Cambridge University. She has an MA in Biblical Studies from King's College London, where she is currently undertaking doctoral research on the use of the Hebrew Bible in the book of Revelation. Fletcher's research interests include feminist hermeneutics, literary and film theory, and textual imitation. [michelle.fletcher@kcl.ac.uk]

Kathryn Kueny is Associate Professor of Theology at Fordham University, where she directs the Middle East Studies and Religious Studies programs. An expert in medieval Islam, Professor Kueny is the author of two books, The Rhetoric of Sobriety: Wine in Early Islam and Conceiving Identities: Maternity 
Reproduced with permission of the copyright owner. Further reproduction prohibited without permission. 